\title{
Egyptian Students' Disinterest in Overseas Academic Mobility: A Behavioral Approach Based on the Capability-Opportunity-Motivation Model
}

\author{
Hélène Syed Zwick \\ ESLSCA University, Egypt
}

\begin{abstract}
This study uses the capability-opportunity-motivation behavior framework as a theoretical basis and partial least squares structural equation modeling as an empirical research method to identify factors that influence the interest in studying abroad. We rely on primary microdata collected through a self-administered questionnaire among Egyptian students and apply a structural equation model to estimate the different relationships. Our analysis yielded interesting results: (a) $58 \%$ of our respondents were somehow interested in studying abroad; (b) physical capability, physical opportunity, and automatic motivation were the main predictors of interest in overseas academic mobility; and (c) a three-pillar policy program based on guidelines, communication and marketing, and regulation could be implemented to promote the interest of young Egyptians in studying abroad.
\end{abstract}

Keywords: behavioral change wheel, behavioral mobility economics, capabilityopportunity-motivation behavior model, Egypt, evidence-based policy

\section{INTRODUCTION}

International student mobility (ISM) has become a crucial fragment of contemporary migration, especially within the context of rapid internationalization of higher educational systems. According to the Organisation 
for Economic Cooperation and Development (OECD, 2019), about 5 million students in tertiary education studied abroad, compared to 0.8 million in 1975. However, while some countries are well inserted within the ISM system like the United States, the United Kingdom, Australia, and Germany, other countries remain at its margin (Perkins \& Neumayer, 2014). This is typically the case of less developed countries from Africa and South America. Unfortunately, scholars have not drawn enough attention to these countries and the inherent trends that occur (see Netz, 2015, among others).

It is precisely this gap that my study desires to emphasize and explore. This study's contribution to the literature is therefore threefold. Firstly, I argue that there is an important gap in ISM research that mostly focuses on students who have been mobile rather than on students in general who are thinking about whether or not to study abroad in the future (King \& Sondhi, 2018; Syed Zwick, 2020a). Arango (2000) explained that most models on migratory processes in general fail to explain why so few people do move. This point of view is also in line with Schewel $(2015,2019)$ who considered this practice as an analytical and methodological mobility bias and Carling (2002) who advised to deconstruct the migration decision-making process into aspiration and ability phases. However, a small number of studies puts emphasis on would-be mobile students (Syed Zwick $\&$ Syed, 2015, for instance), but misses the opportunity to incorporate a behavioral dimension to their analysis. This leads to the second contribution of my study.

Secondly, I claim that current empirical research on ISM fails to systematically include cognitive considerations within a complete behavioral model. I agree with the analysis of Koikkalainen and Kyle (2016) who argued that more empirical research focusing on cognitive migration and on people imagining possible mobile or immobile futures is required in migration research. My study shifts from observed mobility in the present to probable mobility in the future, tht incorporating dreams, thoughts, and feelings but also implying uncertainty and risk (Czaika, 2015). This cognitive approach contributes to the necessary rethinking of economics as an interdisciplinary field, which has been highlighted by the OECD through its New Approaches to Economic Challenges initiative (OECD, 2017). The organization claims that a new narrative is needed to integrate the hopes, values, attitudes, and behaviors of people into economics, along with the facts and data that economists are more used to dealing with. Some studies have explored the influence of cognitive dimensions on the migration decisionmaking process of specific would-be migrants (Schewel, 2015; Syed Zwick, 2020b; Van der Velde \& van Naerssen, 2015).

Thirdly, I call for evidence-based student mobility programs that address needs of students. So far, and to the best of my knowledge, there are a few studies on ISM drawing attention to situations wherein policy decisions are informed by rigorously established objective evidence. My interest in evidence-based student mobility programs reflects the recent and noteworthy revival of the debate on the relationship between research and public policy. Several contributions (Cairney, 2016; Parkhurst, 2017; Stoker \& Evans, 2016) have provided new insights into an old discussion that arose in the late 1970s and early 1980s with Caplan (1979). Like Howes et al. (2018), I argue that basing student mobility programs more 
firmly on sound evidence is even more challenging for less developed countries, commonly characterized by weak institutions and a lack of strong incentives to conduct good programs or policies. My study aims to foster and encourage evidence-based policymaking in the field of ISM in a less developed country, Egypt.

To do so, I rely on two psychological models - Capability-OpportunityMotivation Behavior (COM-B) and the Behavioral Change Wheel (BCW) originally designed by Michie and Prestwich (2010) and Michie et al. (2011), respectively. These models aim to design evidence-based interventions and policies that will be selected transparently and systematically (Michie, Hyder, et al., 2011a). Such models, considered supramodels as they can explain any human behavior, have been successfully applied in health psychology and in the medical field (Alexanders et al., 2014; Barker et al., 2016; Michie, Van Stralen, \& West, $2011 \mathrm{~b}$ ), but never in the field of migration or academic mobility.

This study is finally guided by the following research question: What is the respective influence of capabilities, opportunities, and motivations in students' interest in overseas academic mobility? I empirically focus on Egypt and address this research question through a research design based on a self-administered survey, shaped by the COM-B and $\mathrm{BCW}$ models, and quantitatively estimated through a partial least squares structural equation modeling (PLS-SEM). To that end, I established three hypotheses:

H1: The higher the degree of capability, the higher the interest in academic mobility.

H2: The higher the degree of opportunity, the higher the interest in academic mobility.

H3: The higher the degree of motivation, the higher the interest in academic mobility.

\section{LITERATURE REVIEW}

UNESCO Institute of Statistics (UIS, 2019) measured the total outbound international mobile students' indicator as the number of students who crossed a national border for the purpose of education and were at that time enrolled outside their country of origin. In 2017, this number exceeded 5 million. In terms of total outbound international mobile students in 2017, the Arab region represented 10\%, Asia and the Pacific (42\%), and Central and Eastern Europe and Central Asia $(15 \%)$. In these measures, Egypt has remained at the periphery of the ISM system. On one hand, data show a significant increase in the number of Egyptian students studying abroad since 2008 from 12,000 to 35,000 in 2017. As a result, Egypt was the fourth largest sending country of international students in the Arab world, after Saudi Arabia, Morocco, and Syria (UIS, 2019). On the other hand, Egypt is also the most populous country in the region, with almost 100 million people in 2018. Consequently, while considering the study outbound rate, which gives the number of students from a given country studying abroad, expressed as a percentage of 
total tertiary enrolment in that country, Egypt exhibited the lowest rate in the Arab world despite its increase from $2013(0.83 \%)$ to $2017(1.19 \%)$. As a comparison, Jordan's outbound rate in 2017 was 8 times higher at $8.7 \%$, followed by Lebanon. Morocco and Saudi Arabia, despite a slight decline over time, displayed an outbound rate of 5\% in 2017 (UIS, 2019).

Literature on ISM is vast and growing. Scholars have extensively explored determinants and motivations of students in mobility (Brooks \& Waters, 2011; Findlay et al., 2017; King \& Sondhi, 2018; among others). While mainly relying on economic and financial factors, they distinguish between three main reasons for students to decide to study abroad. The first reason refers to the capacitybuilding thesis (Lowell \& Khadka, 2011; Rosenzweig, 2007). Students rationally decide to study abroad because they see it as a first step toward an international professional career. ISM is therefore first considered a career-enhancing investment by human capital theoreticians (Findlay et al., 2017; King \& Sondhi, 2018; Nilsson \& Ripmeester, 2016), and second, a highly skilled migration or brain circulation (Collins et al., 2017; Rosensweig, 2007).

The second reason refers to opportunistic behavior in a global society where mobility is life-stage consumption good (King \& Sondhi, 2018). This approach goes beyond economics. It belongs to a multidimensional stream in the literature that also includes ethnographic and sociologic studies (Beck \& Beck-Gernsheim, 2002; Cresswell, 2006; Soong et al., 2017; Urry, 2007; Waters, 2008). These latter studies scrutinize social norms of mobility in general based on the Bourdieusian (Bourdieu, 1986) forms of capital. They consider mobile students' international and multicultural experiences as embodied in a specific form of mobility capital (Murphy-Lejeune, 2002; Syed Zwick \& Syed, 2015). Mobility is part of the culture. In their studies, Mondain and Diagne (2013) and Newell (2012) talked about an "almost obligatory rite of passage" (Mondain \& Diagne, 2013, p. 512) and consumption good, respectively.

The third reason refers to the constrained-schooling thesis, which applies to origin countries. This thesis appeared in the 1970s and 1980s and found ground in the emergence of Africa and Asia as postcolonies and origin countries of mobile students (Cummings, 1984; Lee \& Tan, 1984). It states that students study abroad because they lack study and training opportunities in their origin country: Fees might be too high or the tertiary-education supply might be too low, for instance. It therefore assumes that there is a negative relationship between tertiaryeducation supply and education outflows (see Chen, 2007, especially). Neglected for 20 years, Kritz (2016) recently brought it up to date by assessing its relevance to current student outflows.

Such literature has overfocused on motivational factors. From my point of view, the absence of conceptual framework in empirical studies has led to a neglect of other important dimensions of any decision-making processes. Yet, I found a few scholars who adopted behavioralist and cognitive psychology models to explain overseas academic mobility (Kubota, 2016; Lo, 2019). Kubota (2016), for instance, explored and critically examined social imaginary experiences in mobility but without using a well-defined theoretical framework. Lo (2019) 
introduced the capability approach to reframe the meaning of ISM, but the study remained at the theoretical level.

Furthermore, I have noticed that the mobility bias in migration research recently denounced by Schewel (2019) concerns studies on ISM as well. As far as I know, very few academic studies have attempted to explain student immobility and the lack of interest in overseas academic mobility in general (Breines et al., 2019; British Council, 2017; Syed Zwick \& Syed, 2015). For example, the British Council has been publishing a Broadening Horizons report on a yearly basis to communicate the evolution and degree of interest of students in study abroad. Over time, the percentage of students reporting a disinterest in study abroad has varied from $80 \%$ in 2013 , to $66 \%$ in 2015 , and to $82 \%$ in 2017 , raising concerns about the factors explaining this high structural proportion. Among the key motivators identified in the report are language training, information on funding, and evidence of positive labor market outcomes. Such a study is instructive; however, the survey does not rely on any solid theoretical framework, leading to omission of substantial dimensions critical to understanding the ISM decision-making process. In the present study, I propose a theoretically founded empirical analysis that allows us to methodically identify the three predictors that explain this process.

\section{CONCEPTUAL FRAMEWORK}

\section{The COM-B Model}

The COM-B model offers a comprehensive, parsimonious, and applicable model to all behaviors (Barker et al., 2016). It articulates three conditions or predictors, which are capability, opportunity, and motivation. These elements are considered important drivers to transit from a behavioral intent and ideation to a behavior. In other words, they deconstruct the decision-making process. Figure 1 represents the model and indicates that motivational factors ground a behavioral intention and ideation to the individual. This intention is usually defined as a person's perceived likelihood or subjective probability that they will engage in a given behavior. This intention depends on motivational factors, but is moderated also by opportunistic and capability factors. According to Michie, Stralen, and West (2011), motivational factors activate or inhibit behavior, opportunistic factors enable the behavior, while capability factors enact it.

Capability is the first predictor of the COM-B model. It is defined by Michie, Van Stralen, and West (2011) as the "individual's psychological and physical capacity to engage in the activity concerned. It includes having the necessary knowledge and skills. [...] We distinguish between physical and psychological capability" (p. 4). Psychological capability is the capacity to engage in the necessary thought processes in reference to comprehension or reasoning, while physical capability relates to skills. Individuals must possess the appropriate set of skills in the relevant area to be able to perform a given behavior. In our case, studying abroad could imply adaptability, personal care, and independence among others. 

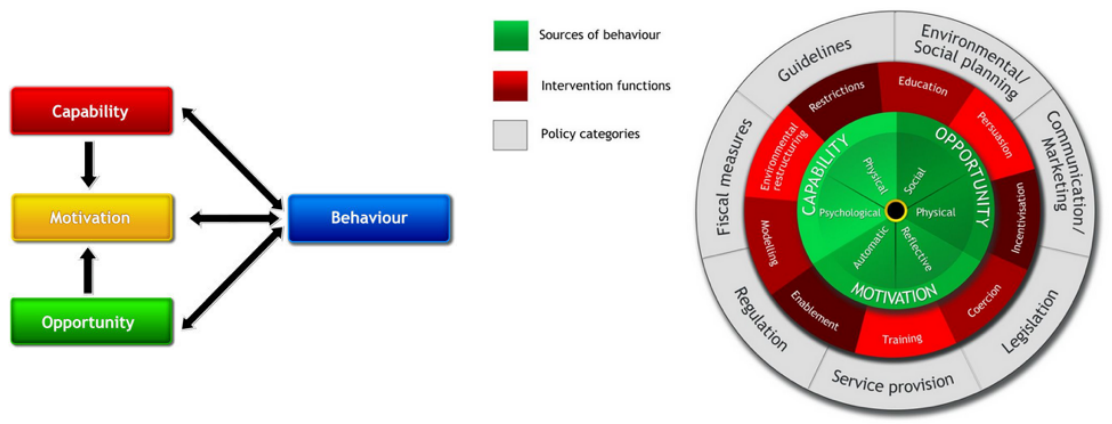

Figure 1: The COM-B Representation (Michie et al., 2011b)

Opportunity is the second predictor of the COM-B model. It is defined as the external circumstances that allow for or facilitate people to perform a behavior (Hung \& Petrick, 2012). It points out the behavior under external environmental constraints (Lai et al., 2018). This definition reflects on the concept of facilitating conditions developed by Triandis (1977) in his theory of interpersonal behavior. Triandis stated that individuals may have the intention to perform a certain act; however, they may be unable to do so as the environment prevents the act from being performed. In my study, I distinguish between physical and social opportunity. While the first refers to opportunities afforded by the environment, including time, location, and resources, the latter is defined as opportunities afforded by social factors, including cultural norms. Physical opportunity occurs when there are no time, material, energy, knowledge, or geographical constraints limiting the individual's desires to be mobile and study abroad. Regarding social opportunity, cultural norms are attitudes and behaviors that are considered typical or average within a society or a group. Literature distinguishes four degrees of cultural norms: the taboo, the laws, folkway, and mores. A taboo is a topic refrained from being talked over normally and implies harsh consequences if broken, while a folkway is a taboo for which breaking the topic does not cause such severe impact. Mores denote topics that sound normal in usual circumstances in a given society, while the last degree is laws, which correspond to a set of agreed rules and regulations. Social culture is another dimension of the social factor, which is a complex set of meanings, habits, and values adopted by one or more social formations like the family or peers. Studying abroad could be seen in Egypt as a folkway and even a habit for some individuals. Finally, more generally, opportunities can be reframed into possibilities.

Finally, the third predictor of the COM-B model is motivation. This factor can directly affect the occurrence of individual behaviors, in terms of intensity but also direction (Bettman, 1979; Hung \& Petrick, 2012). Following Michie, Van Stralen, and West (2011), I consider two types of motivation. Reflective motivation, on one side, involves evaluations and plans, while automatic 
motivation, on the other, involves emotions and impulses that arise from associative learning and/or innate dispositions. Reflective motivation could be seen as an extrinsic motivation that arises from the outside and leads to the exhibiting of a behavior to avoid a penalty or earn a reward. It may include parental expectations or expectations of other trusted role models. Similarly, automatic motivation could be seen as an intrinsic motivation that derives from intangible factors arising from within and that is personally rewarding. Intrinsic motivational factors are generally long-lasting and self-sustaining but slow to affect behaviour. On the opposite, extrinsic motivational factors usually more readily produce behavior changes and typically involve little effort, but mainly are changes in the short run. Over time, they tend to disappear. When applied to overseas mobility, extrinsic motivators relate to labor market outcomes and social identity.

It is worth noticing that there is a bidirectional relationship between these three predictors and behavior. Such relationship is represented in Figure 1 by the double-headed arrow. Also, behavior is defined as an action that is observable and measurable. This is often a response of an individual or group of individuals to an action, environment, person or stimulus. The COM-B is a starting-point to design interventions that aim to impulse a change in behavior.

\section{The BCW Model}

Designed originally by Michie, van Stralen, and West (2011), the BCW model aims to improve the systematic and transparent identification and design of effective behavior change interventions and policy areas. The authors defined these intervention functions as coordinated sets of activities designed to change specified behavior patterns. Such are measured in terms of prevalence or incidence of specific behaviors in a specified population (Figure 1).

The $\mathrm{BCW}$ model provides a framework of these interventions based on the three predictors. The framework defines nine intervention functions that aim to address deficits in one or more of these conditions. These functions are education, restriction, environmental restructuring, modeling, enablement, training, coercion, incentivization, and persuasion. Articulated around these nine intervention functions are seven categories of policy that could enable those interventions to occur. These are guidelines, fiscal measures, regulation, service provision, legislation, communication and marketing, and environmental and social planning.

\section{METHOD}

\section{Operationalization of the COM-B Framework}

The operationalization of the COM-B framework consisted of identifying a gap between the target behavior-increasing outward student mobility-and effective behaviors - not interested in student mobility. I sought to analyze whether the targets of the intervention, namely students, have the capability, 
opportunity, and motivation to perform the target behavior-studying abroad. For each of them $(\mathrm{C}, \mathrm{O}$, and $\mathrm{M})$, I assigned different potential influencing factors and formulated six general assessments in line with the definitions given in the theoretical framework. The general assessments come from empirical evidence. I also used a common answer scale across the three groups of constructs based on a 5-point Likert scale ( $1=$ I totally disagree; $5=$ I totally agree $)$.

I started with the capability predictor. Its operationalization is given in Table 1. The six general assessments are noted as $\mathrm{C} 1-\mathrm{C} 6$. From the operationalization, I established my first hypothesis:

H1: The higher the degree of capability, the higher the interest in academic mobility.

With regards to opportunity, I used six general assessments from $\mathrm{O} 1$ to $\mathrm{O6}$. Table 1 displays constructs, reflecting physical opportunity on one side (O1-O2) and social opportunity on the other (O3-O6). The second hypothesis is as follows:

$\mathrm{H} 2$ : The higher the degree of opportunity, the higher the interest in academic mobility.

Finally, I operationalized the motivation predictor. Both reflective and automatic motivation have three constructs (M1-M3 and M4-M6). The third hypothesis is as follows:

H3: The higher the degree of motivation, the higher the interest in academic mobility.

Regarding the endogenous predictor, which refers to the behavior itself, I operationalized it through a single-item construct. I used self-reported degree of interest in academic mobility by using the following Likert-scaled question: Rate your interest in studying abroad from 1 (I am not at all interested) to 5 (I am very interested).

Table 1: Operationalizing the Predictors

\begin{tabular}{|c|c|c|c|}
\hline ID & Domains & Constructs & General assessments \\
\hline \multicolumn{4}{|c|}{ Capability predictor } \\
\hline $\mathrm{C} 1$ & Physical & Skills & $\begin{array}{l}\text { I have the required skills to } \\
\text { study abroad. }\end{array}$ \\
\hline $\mathrm{C} 2$ & & $\begin{array}{l}\text { Skills } \\
\text { development }\end{array}$ & $\begin{array}{l}\text { I believe that studying abroad } \\
\text { would not be beyond my } \\
\text { control. }\end{array}$ \\
\hline $\mathrm{C} 3$ & & $\begin{array}{l}\text { Skills } \\
\text { development }\end{array}$ & $\begin{array}{l}\text { I can handle being on my own } \\
\text { abroad. }\end{array}$ \\
\hline $\mathrm{C} 4$ & Psychological & $\begin{array}{l}\text { Procedural } \\
\text { knowledge }\end{array}$ & $\begin{array}{l}\text { I know how to plan to study } \\
\text { abroad. }\end{array}$ \\
\hline
\end{tabular}




\begin{tabular}{|c|c|c|c|}
\hline ID & Domains & Constructs & General assessments \\
\hline $\mathrm{C} 5$ & & Knowledge & $\begin{array}{l}\text { I have knowledge about the } \\
\text { benefits of studying abroad. }\end{array}$ \\
\hline C6 & & Knowledge & $\begin{array}{l}\text { I have no concerns in studying } \\
\text { abroad. }\end{array}$ \\
\hline \multicolumn{4}{|c|}{ Opportunity predictor } \\
\hline O1 & Physical & Barriers & $\begin{array}{l}\text { It is easy to plan for studying } \\
\text { abroad. }\end{array}$ \\
\hline $\mathrm{O} 2$ & & Resources & I can afford studying abroad. \\
\hline O3 & Social & $\begin{array}{l}\text { Environmental } \\
\text { stressors }\end{array}$ & $\begin{array}{l}\text { Studying abroad is well } \\
\text { accepted in the Egyptian } \\
\text { society. }\end{array}$ \\
\hline $\mathrm{O} 4$ & & Social pressure & $\begin{array}{l}\text { My relatives and friends } \\
\text { pressure me to study abroad. }\end{array}$ \\
\hline O5 & & Social support & $\begin{array}{l}\text { My university supports } \\
\text { academic student mobility. }\end{array}$ \\
\hline O6 & & Group norm & $\begin{array}{l}\text { I have relatives and friends } \\
\text { who studied abroad. }\end{array}$ \\
\hline \multicolumn{4}{|c|}{ Motivation predictor } \\
\hline M1 & Reflective & Identity & $\begin{array}{l}\text { I believe that studying abroad } \\
\text { would positively change who I } \\
\text { am. }\end{array}$ \\
\hline $\mathrm{M} 2$ & & Social identity & $\begin{array}{l}\text { I believe that studying abroad } \\
\text { would improve the image my } \\
\text { family and friends have about } \\
\text { me. }\end{array}$ \\
\hline M3 & & Optimism & $\begin{array}{l}\text { I believe that studying abroad } \\
\text { can positively affect my } \\
\text { professional career. }\end{array}$ \\
\hline M4 & Automatic & Belief & $\begin{array}{l}\text { Overall, I am satisfied with } \\
\text { myself. }\end{array}$ \\
\hline M5 & & Positive affect & $\begin{array}{l}\text { When I try, I generally } \\
\text { succeed. }\end{array}$ \\
\hline M6 & & Interest & $\begin{array}{l}\text { My interest in studying abroad } \\
\text { has increased over time. }\end{array}$ \\
\hline
\end{tabular}

Note. 1 =I totally disagree, 2 =I agree $; 3=$ Neither $\ldots$ Nor $; 4=I$ disagree $; 5=I$ totally agree. 


\section{Data Collection}

I used primary microdata collected through a self-administered questionnaire that I distributed in greater Cairo and its suburbs. I included two screening questions at the beginning of the questionnaire, after a brief introduction and consent, to limit participation to those who were actually Egyptians studying in a public or private university based in Egypt.

I designed and implemented the questionnaire in Arabic rather than in English. My choice was motivated by the willingness to avoid any self-selection bias. A questionnaire in English would have naturally selected Egyptian students with English skills and knowledge, while the national and official language in Egypt is Arabic. The sample of respondents would not have been representative of the whole student population, which could lead to bias the findings and then to spurious results. Because I am not an Arabic native, I utilized a specific method. I elaborated first the questionnaire in English. Then, a professional Egyptian translator, familiar with economic topics, translated the English version to Arabic. In order to validate the translated version, I used the back-translation method that allows for a second professional Egyptian translator to translate this second version into English. I then compared the first and second English versions. I had to adjust few sentences, before reiterating the process one more time. I found no differences between the third versions. Additionally, I launched a pilot survey with 10 student respondents in order to avoid any cultural offense. This pilot survey did not raise any issue. There were no missing data for the survey responses as the participants responded in person. On average, respondents took $6 \mathrm{~min}$ to answer the questionnaire.

I distributed the survey during 4 months from October 1, 2018, to February 25,2019 . The study finally relied on a primary microdataset of 484 participants who voluntarily accepted to complete the survey. In order to increase the respondent rate, I used the snowball sampling technique.

Descriptive statistics indicate that most respondents were women $(62 \%$ of the total sample), aged between 18 and 25 years old ( $M=22$ years old). On average, the majority $(58 \%)$ of respondents mentioned that they were somewhat interested in studying abroad (rating at least 3 out of 5).।

\section{Structural Equation Modeling}

SEM is a second generation of multivariate analysis methods that appeared in the early 1990s. Developed for analyzing complex interrelationships among both unobserved (latent) and observed variables in a model simultaneously, such models benefit from a growing interest in diverse academic fields (Hair et al., 2012). According to Ullman (2001), SEM is a combination of factor analysis and linear regression. It analyzes the direct and indirect effects of a series of moderators on the relationship between the independent and dependent variables. There are several advantages of SEM over regression that are well discussed in Bollen and Pearl (2013). Among others, SEM allows for the estimation of 
multiple and interrelated dependence relationships and for the representation of unobserved concepts in these relationships.

Econometrics literature offers competing SEM approaches - the co-variancebased and variance-based. In order to choose between both, I referred to the rule of thumb provided by Hair et al. (2012) and more recently by Hair et al. (2017). The authors explained that when a study has an exploratory dimension based on a small sample size, and it aims to identify key driver constructs on one side, and include formatively measured constructs in opposition to reflectively measured ones, a variance-based approach is preferable over a co-variance approach. More specifically, variance-based estimators give proxies for constructs before estimating model parameters based on these proxies. Among the variance-based approach, I selected the PLS-SEM approach, which is considered "the most fully developed and general system" (McDonald, 1996, p. 240). The estimator uses ordinary least squares (OLS) based on a nonparametric bootstrap technique to test for the significance of the coefficients.

PLS-SEM models consist of two main elements: a structural model and a measurement model. The structural model shows the associations - graphically represented by a path between the formatively measured constructs (represented by circles). The measurement model displays the associations between these constructs and the indicator variables (graphically represented by rectangles). In my case, I had exogenous constructs, which were my three predictors (capability, opportunity, and motivation) on one side, and an endogenous construct, which referred to my variable of interest, namely the interest in academic mobility. All of them were the latent variables of my proposed model. The indicator variables, which were also the observed variables (or the responses in the questionnaire), were used to represent these three exogenous variables in the statistical model. The model estimates the associations between the latent variables and explains the target constructs of interest. In other terms, the PLS-SEM approach allowed me to estimate weights between indicator variables and constructs, on one side, and latent variable scores, on the other.

Figure 2 displays my research model. The general statements presented in Table 1 were used to identify the impact of individual indicator constructs within the three predictors of the COM-B model on the degree of interest in student mobility. 


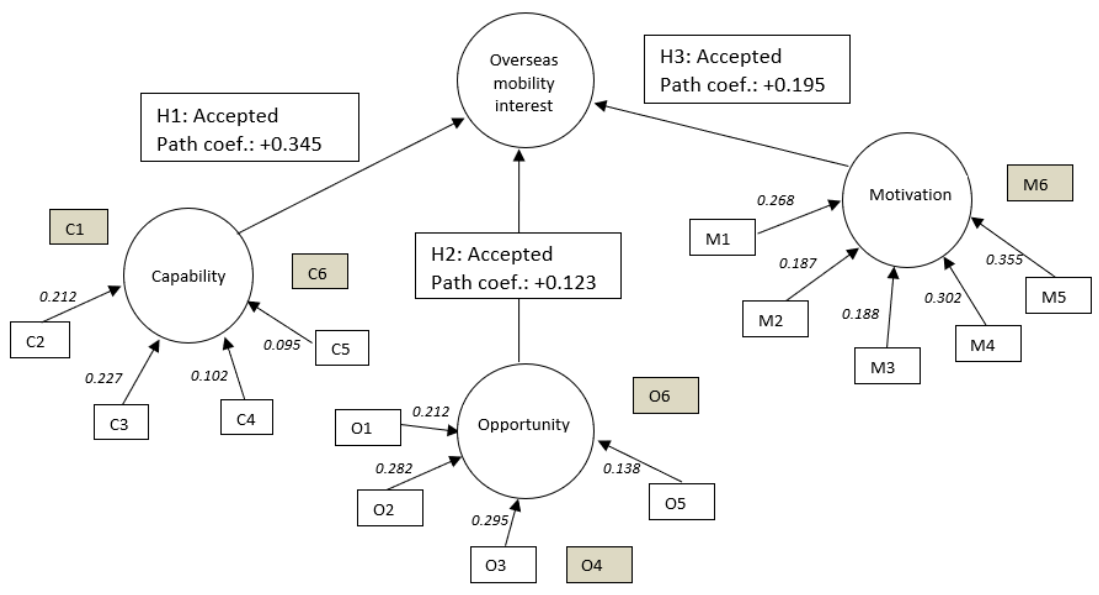

Figure 2: Proposed Research Model

\section{RESULTS}

In order to obtain a valid research model, I assessed both the measurement model and the structural model. With regard to the measurement model, I checked for collinearity through the variance inflation factors and for significance and relevance of the constructs' indicators. With regard to the structural model, I evaluated the coefficient of determinant $R^{2}$ and path coefficients. ${ }^{1}$ Figure 2 displays the final estimated research model.

\section{Hypothesis Testing: Focusing on the Structural Model}

All path coefficients for the three predictors had a significant and positive impact on the interest in overseas academic mobility. They also had a value higher than 0.2, which interprets the COM-B predictors as meaningful (Nitzl, 2016). My three hypotheses were therefore accepted, but the path coefficient in scale differed significantly across them. While the path coefficient equaled .345 between capability and interest in studying abroad, it equaled .123 and .195 for motivation and opportunity, respectively. Additionally, I noted that size effects were different in scale and relatively low for the capability and motivation predictors $(.025$ and .017 , respectively). Figure 2 and Table 2 display the findings of my hypotheses.

${ }^{1}$ Results are available upon request. 
Table 2: Structural Model Results

\begin{tabular}{lcccc}
\hline & $\begin{array}{c}\text { Path } \\
\text { Effect }\end{array}$ & \\
Path & coefficient & $p$ & sizes & Decision \\
\hline Capability $\rightarrow$ academic interest & .345 & .000 & .025 & H1: Accepted \\
Opportunity $\rightarrow$ academic interest & .123 & .000 & .184 & H2: Accepted \\
Motivation $\rightarrow$ academic interest & .195 & .000 & .017 & H3: Accepted \\
\hline
\end{tabular}

\section{Indicator Constructs Evaluation: Focusing on the Measurement Model}

Table 3 shows the results of the measurement model. Out of 18, there were 13 formative indicators that had significant weights at the $10 \%$ level. Five items were found insignificant and were therefore not included in the final PLS-SEM (C1, C6, O4, O6, and M6).

Table 3: Measurement Model Results

\begin{tabular}{llccc}
\hline Path calculations & Indicators & Weights & Loadings & $p$ (weights) \\
\hline Capability +.345 & $\mathrm{C} 2 * * *$ & .212 & .425 & .000 \\
& $\mathrm{C} 3^{* * *}$ & .227 & .447 & .001 \\
& $\mathrm{C} 4 * *$ & .102 & .224 & .065 \\
& $\mathrm{C} 5 * *$ & .094 & .344 & .011 \\
Opportunity +.123 & $\mathrm{O} 1^{* * *}$ & .212 & .385 & .001 \\
& $\mathrm{O} 2^{* * *}$ & .282 & .315 & .001 \\
& $\mathrm{O} 3^{* * *}$ & .295 & .474 & .001 \\
& $\mathrm{O} 5^{* * *}$ & .138 & .452 & .000 \\
Motivation +.195 & $\mathrm{M} 1^{* * *}$ & .268 & .385 & .001 \\
& $\mathrm{M} 2^{* *}$ & .187 & .244 & .065 \\
& M3** & .188 & .258 & .058 \\
& M4*** & .302 & .564 & .003 \\
& M5*** & .355 & .284 & .004 \\
\hline
\end{tabular}

Note. Bootstrapping: 5,000 samples $(n=484)$. PLS estimation algorithm: Mode A/correlation weights. ${ }^{* *} p<.01,{ }^{* *} p<.05,{ }^{*} p<.10$.

Starting with the indicators of the capability predictor, my results interestingly indicated that assessments $\mathrm{C} 2$, I believe that studying abroad would not be beyond my control, and C3, I can handle being on my own abroad, had the highest outer weights (.212 and .227), while assessment C5, I have knowledge about the benefits of studying abroad, was associated with the lowest one (.094). Such findings reveal the crucial role of physical capability in the degree of interest in studying abroad, despite the non-significance of assessment $\mathrm{C} 1$.

With regard to opportunistic factors, two assessments, construct $\mathrm{O} 5, \mathrm{My}$ university supports academic student mobility, which reflected social support, showed the lowest outer weight within this dimension with a value of .138. On 
the contrary, assessments $\mathrm{O} 1, \mathrm{O} 2$, and $\mathrm{O} 3$ that belonged to physical opportunity displayed the highest outer weights with $.295, .282$, and .212, respectively.

Finally, with regard to motivational factors, only one assessment (M6) appeared not significant, My interest in studying abroad has increased over time. Automatic motivation associated with assessments M4, Overall, I am satisfied with myself, and M5, When I try, I generally succeed, had the highest outer weights within the motivational dimension, with .302 and .355 , respectively.

\section{DISCUSSION}

While the academic literature examining ISM has primarily focused on economic, financial, and social factors to understand study abroad decision-making processes, I have argued that the complexity of any decision-making process necessitates that, in addition to such factors, we must assess the role of psychologic factors that can drive the interest in overseas mobility using a conceptual framework well-known in psychology studies. Results confirm my argument, and the relevance of the COM-B model to explain the interest of students in overseas academic mobility in three dimensions-capability, opportunity, and motivation - is meaningful. This corroborates the fact that the study abroad decision-making process depends on a complex combination of economic, financial, social, and psychologic factors.

In the context of the predictor of capability, my first hypothesis was confirmed, and results highlighted its critical role in overseas mobility interest. Two main constructs related to skills development were crucial in this context: $I$ believe that studying abroad would not be beyond my control and I can handle being on my own abroad. Unfortunately, I acknowledge two main weaknesses in previous literature that explain the lack of empirical evidence on these dimensions: First, there is an overrepresentation of economic, social, and financial factors in the study of determinants of ISM (Brooks \& Waters, 2011; Findlay et al., 2017; King \& Sondhi, 2018, especially) and a lack of psychologic factors. Second, there is a general mobility bias (Schewel, 2019) that prevents focusing on students who are not interested in studying abroad. Traveling and living abroad on your own is challenging and requires significant effort to adapt and adjust to new social and cultural environments. As highlighted by Goodwin and Nacht (1988), living abroad offers more opportunities for change than almost any other human endeavor. This transformative experience that triggers personal growth and self-awareness may be too stressful for many individuals. A positive psychology approach briefly appeared in the British Council's report (2017) and Beerkens et al. (2016).

With respect to the predictor of opportunity, my second hypothesis was validated. Social opportunities related to environmental stressors (studying abroad is well accepted in the Egyptian society) was the most crucial factor. As highlighted in theory and previous literature, social norms play a role in behavior and decision-making processes. In my case, overseas mobility in Egypt appears as a habit and well-accepted norm, far from being a taboo, suggesting that the approach stating that mobility is a life-stage consumption good may be relevant 
in the Egyptian context. Support for this can be found in Soong et al. (2017), Mondain and Diagne (2013), and Waters (2008). The second most crucial factor within opportunity is resources. Highlighted in Beerkens et al. (2016) and SoutoOtero et al. (2013), financial concerns are consistently identified as secondary factors. My findings are consistent with such trends despite the fact that Egypt is a developing country where average disposable income is lower than developed countries, where most studies took place.

Finally, with regard to my third hypothesis and the predictor of motivation, my results confirmed the crucial role of motivators in the decision-making process, as highlighted in previous empirical literature (Findlay et al., 2017; King \& Sondhi, 2018; Lee \& Tan, 1984; Lowell \& Khadka, 2011; Nilsson \& Ripmeester, 2016). However, my study goes a step further by distinguishing between intrinsic and extrinsic motivators. In this study, findings show that intrinsic motivators through belief and positive affect are primary factors. Interestingly, high levels of self-esteem and self-satisfaction were associated with academic advantages such as greater student engagement and academic selfefficacy, implying higher likelihood to be interested in overseas mobility (Ojeda et al., 2011). In this sense, such a dimension is related to cognitive dispositions highlighted within the capability predictor. On the opposite hand, extrinsic motivators seemed to play a secondary role. As explained earlier, theory states that extrinsic motivation that includes parental expectations and expectations of other trusted role models does not require extensive knowledge of individual students.

\section{CONCLUSION}

In this study, I have argued that research in ISM requires a more systematic approach that includes a cognitive dimension and that focuses on those who are not studying abroad yet. Such an approach will allow scholars to transparently and systematically identify and design effective evidence-based interventions and policies to boost students' interest in overseas studies.

Thanks to a primary dataset collected among Egyptian students, I quantified the influence of different factors associated with the COM-B framework. Findings obtained through a PLS-SEM highlighted the primordial role of physical capability, physical opportunity, and automatic motivation. The study's respondents seemed to suffer from a lack of self-confidence and independence. They did not feel comfortable with being on their own in a foreign country and having to autonomously handle their life. In order to increase the interest in overseas academic mobility, it appears therefore timely to simultaneously address these three dimensions when it comes to designing student mobility programs.

Using the $\mathrm{BCW}$, I was able to formulate effective functional interventions and policy areas that would contribute to increase the interest in overseas studies. Three pillars characterize my policy program: The first pillar is based on the use of guidelines, which implies the creation of documents that present and discuss ISM's best practices. This goes hand in hand with the second pillar that consists of communication and marketing. The use of broadcast media especially could be 
critical to induce positive feelings or stimulate actions toward overseas mobility. Finally, the third pillar consists of regulating behavior to enable students feel more self-confident by, for instance, providing students with role-model to aspire to and by offering psychologic support and counseling to reframe opportunities into possibilities.

This study confirms that interest in overseas academic mobility is a complex behavioral issue that requires considering both traditional factors (economic, social, political) and contemporary ones (cognitive). For this reason, I would argue that scholars who integrate this dimension into their future empirical research projects in this field will find not only an original but also a valuable means of understanding the interest in overseas academic mobility.

\section{Limitations and Future Studies}

This paper has several limitations. First, my analysis does not allow for any causal interpretations as the data are cross-sectional. A longitudinal perspective would be useful to track changes over time in motivations, opportunities, and capabilities and their effect on the degree of interest in overseas mobility. Second, the sample was not representative of the whole Egyptian student population. Due to the lack of sampling frame at the national level, the generalization of results is therefore not possible. For future research, I suggest implementing a random sampling strategy on a larger scale and for comparative purposes, to replicate my approach across other countries. Third, data were collected before the COVID-19 pandemic. Given the socioeconomic and behavioral changes on the one hand and international travel restrictions on the other, mobility considerations and mobility decision-making processes have necessarily been affected. With regard to further research, I therefore recommend building a measurement model that would include these new parameters especially through the opportunity channel within the COM-B framework. Nonetheless, the present study can still be seen as a substantial contribution to a better and comprehensive understanding of the ISM decision-making process.

\section{REFERENCES}

Alexanders, K. E., Brijnath, B., \& Mazza, D. (2014). Barriers and enablers to delivery of the Healthy Kids Check: An analysis informed by the theoretical domains framework and COM-B model. Implementation Science, 9(1), Article 60. https://doi.org/10.1186/1748-5908-9-60

Arango, J. (2000). Explaining migration: A critical review. International Social Science Journal, 52(165), 283-296.

Barker, F., Atkins, L., \& de Lusignan, S. (2016). Applying the COM-B behaviour model and behaviour change wheel to develop an intervention to improve hearing-aid use in adult auditory rehabilitation. International Journal of Audiology, 55(3), S90-S98. https://doi.org/10.3109/14992027.2015.1120894

Beck, U., \& Beck-Gernsheim, E. (2002). Individualization. SAGE. 
Beerkens, M., Souto-Otero, M., de Wit, H., \& Huisman, J. (2016). Similar students and different countries? An analysis of the barriers and drivers for Erasmus participation in seven countries. Journal of Studies in International Education, 20(2), 184-204. https://doi.org/10.1177/1028315315595703

Bettman, J. R. (1979). An information processing view or consumer choice. Addison-Wesley.

Bollen, K. A., \& Pearl, J. (2013). Eight myths about causality and structural equation modeling. In S. L. Morgan (Ed.), Handbook of causal analysis for social research (pp. 301-328). Springer.

Bourdieu, P. (1986). The forms of capital. In J. G. Richardson (Ed.), Handbook for theory and research in the sociology of education (pp. 241-258). Greenwood Press.

Breines, M. R., Raghuram, P., \& Gunter, A. (2019). Infrastructures of immobility: Enabling international distance education students in Africa to not move. Mobilities, 14(4), 484-499. https://doi.org/10.1080/17450101.2019.1618565

British Council. (2017). Broadening horizons 2017: Addressing the needs of a new generation. https://www.britishcouncil.org/education/he-science/knowledgecentre/student-mobility/broadening-horizons-2017-addressing-needs-new

Brooks, R., \& Waters, J. (2011). Student mobilities, migration and the internationalization of higher education. Palgrave Macmillan.

Cairney, P. (2016). The politics of evidence-based policy making. Springer.

Caplan, N. (1979). The two-communities theory and knowledge utilization. American Behavioral Scientist, 22, 459-470. https://doi.org/10.1177/000276427902200308

Carling, J. (2002). Migration in the age of involuntary immobility: Theoretical reflections and Cape Verdean experiences. Journal of Ethnic and Migration Studies, 28(1), 5-42. https://doi.org/10.1080/13691830120103912

Chen, L. H. (2007). East-Asian students' choice of Canadian graduate schools. International Journal of Education Advancement, 7(4), 271-306. https://doi.org/10.1057/palgrave.ijea.2150071

Collins, F. L., Ho, K. C., Ishikawa, M., \& Ma, A. H. (2017). International student mobility and after-study lives: The portability and prospects of overseas education in Asia. Population, Space and Place, 23, Article e2029. https://doi.org/10.1002/psp.2029

Cresswell, T. (2006). On the move. Routledge.

Cummings, W. K. (1984). Going overseas for higher education: The Asian experience. In E. G. Barber, P. G. Altbach, \& R. G. Myers Eds.), Bridges to knowledge: Foreign students in comparative perspective (pp. 130-146). University of Chicago Press.

Czaika, M. (2015). Migration and economic prospects. Journal of Ethnic and Migration Studies, $\quad 41(1), \quad 58-82$. https://doi.org/10.1080/1369183X.2014.924848

Findlay, A. M., King, R., \& Stam, A. (2017). Producing international student migration: An exploration of the role of marketization in shaping international study opportunities. In M. van Riemsdijk \& Q. Wang (Eds.), Rethinking international skilled migration (pp. 19-35). Routledge. 
Goodwin, C. D., \& Nacht, M. (1988). Abroad and beyond: Patterns in American overseas education. Cambridge University Press.

Hair, J. F., Hult, G. T. M., Ringle, C. M., \& Sarstedt, M. (2017). A primer on partial least squares structural equation modeling (2nd ed.). SAGE.

Hair, J. F., Ringle, C. M., \& Sarstedt, M. (2012). Partial least squares: The better approach to structural equation modeling? Long Range Planning, 45(5-6), 312-319. https://doi.org/10.1016/j.lrp.2012.09.011

Howes, S., Betteridge, A., Sause, L., \& Ugyel, L. (2018). Evidence-based policy making in the tropics: Are developing countries different? Development Policy Centre Discussion Paper 59. https://dx.doi.org/10.2139/ssrn.3009196

Hung, K., \& Petrick, J. F. (2012). Testing the effects of congruity, travel constraints, and self-efficacy on travel intentions: An alternative decisionmaking model. Tourism Management, 33(4), 855-867. https://doi.org/10.1016/j.tourman.2011.09.007

King, R., \& Sondhi, G. (2018). International student migration: A comparison of UK and Indian students' motivations for studying abroad. Globalisation, Societies and Education, 16(2), 176-191. https://doi.org/10.1080/14767724.2017.1405244

Koikkalainen, S., \& Kyle, D. (2016). Imagining mobility: The prospective cognition question in migration research. Journal of Ethnic and Migration Studies, 42(5), 759-776. https://doi.org/10.1080/1369183X.2015.1111133

Kritz, M. M. (2016). Why do countries differ in their rates of outbound student mobility? Journal of Studies in International Education, 202, 99-117. https://doi.org/10.1177/1028315315598104

Kubota, R. (2016). The social imaginary of study abroad: Complexities and contradictions. The Language Learning Journal, 44(3), 347-357. https://doi.org/10.1080/09571736.2016.1198098

Lai, H. M., Hsiao, Y. L., \& Hsieh, P. J. (2018). The role of motivation, ability, and opportunity in university teachers' continuance use intention for flipped teaching. Computers and Education, 124, 34-50. doi:10.1016/j.compedu.2018.05.013

Lee, K. H., \& Tan, J. P. (1984). The international flow of third level lesser developed country students to developed countries: Determinants and implications. Higher Education, 13, 687-707. https://doi.org/10.1007/BF00137020

Lo, W. Y. (2019). Beyond competition: A comparative review of conceptual approaches to international student mobility. Globalisation, Societies and Education, 17(3), 261-273. https://doi.org/10.1080/14767724.2018.1525283

Lowell, B. L., \& Khadka, P. (2011). Trends in foreign-student admissions to the U.S. In B. R. Chiswick (Ed.), High-skilled immigration in a global labor market (pp. 83-110). American Enterprise Institute.

McDonald, R. P. (1996). Path analysis with composite variables. Multivariate Behavioral Research, 31(2), 239-270. https://doi.org/10.1207/s15327906mbr3102_5 
Michie, S., Hyder, N., Walia, A., \& West, R. (2011). Development of a taxonomy of behaviour change techniques used in individual behavioural support for smoking cessation, Addictive Behaviours, 36(4), 315-319. http://dx.doi.org/10.1016/j.addbeh.2010.11.016

Michie, S., \& Prestwich, A. (2010). Are interventions theory-based? Development of a theory coding scheme. Health Psychology, 29(1), 1-8. https://doi.org/10.1037/a0016939

Michie, S., Van Stralen, M. M., \& West, R. (2011). The behaviour change wheel: A new method for characterizing and designing behaviour change interventions. Implementation Science, 6(1), Article 42. https://doi.org/10.1186/1748-5908-6-42

Mondain, N., \& Diagne, A. (2013). Discerning the reality of 'those left behind' in contemporary migration processes in Sub-Saharan Africa: Some theoretical reflections in the light of data from Senegal. Journal of Intercultural Studies, 345, 503-516. https://doi.org/10.1080/07256868.2013.827831

Murphy-Lejeune, E. (2002). Student mobility and narrative in Europe: The new strangers. Routledge.

Netz, N. (2015). What deters students from studying abroad? Evidence from four European countries and its implications for higher education policy. Higher Education Policy, 28(2), 151-174. https://doi.org/10.1057/hep.2013.37

Newell, S. (2012). The modernity bluff: Crime, consumption, and citizenship in Côte d'Ivoire. University of Chicago Press.

Nilsson, P. A., \& Ripmeester, N. (2016). International student expectations: Career, opportunities and employability. Journal of International Students, $6(2), 614-631$.

Nitzl, C. (2016). The use of partial least squares structural equation modelling (PLS-SEM) in management accounting research: Directions for future theory development. Journal of Accounting Literature, 39, 19-35. https://doi.org/10.1016/j.acclit.2016.09.003

Ojeda, L., Flores, L. Y., \& Navarro, R. L. (2011). Social cognitive predictors of Mexican American college students' academic and life satisfaction. Journal of Counseling Psychology, 58, 61-71. https://doi.org/10.1037/a0021687

Organisation for Economic Cooperation and Development. (2017). Debate the issues: Complexity and policy making. OECD Insights. http://dx.doi.org/10.1787/9789264271531-en

Organisation for Economic Cooperation and Development. (2019). Education at a glance 2019: OECD indicators. https://doi.org/10.1787/f8d7880d-en

Parkhurst, J. (2017). The politics of evidence: From evidence-based policy to the good governance of evidence. Routledge.

Perkins, R., \& Neumayer, E. (2014). Geographies of educational mobilities: Exploring the uneven flows of international students. The Geographical Journal, 180(3), 246-259. https://doi.org/10.1111/geoj.12045

Rosenzweig, M. R. (2007). Higher education and international migration in Asia: Brain circulation [Paper presentation]. Regional Bank Conference on Development Economics, Beijing. 
Schewel, K. (2015). Understanding the aspiration to stay. Oxford University International Migration Institute Working Papers No. 107.

Schewel, K. (2019). Understanding immobility: Moving beyond the mobility bias in migration studies. International Migration Review, 54(2), 328-355. https://doi.org/10.1177/0197918319831952

Soong, H., Stahl, G., \& Shan, H. (2017). Transnational mobility through education: a Bourdieusian insight on life as middle transnationals in Australia and Canada. Globalisation, Societies and Education, 16(2), 241-253. https://doi.org/10.1080/14767724.2017.1396886

Souto-Otero, M., Huisman, J., Beerkens, M., \& de Wit, H. (2013). Barriers to international student mobility: Evidence from the ERASMUS program. Educational Researcher, 42, 70-77.

Stoker, G., \& Evans, M. (2016). Evidence-based policy making in the social sciences: Methods that matter. Policy Press.

Syed Zwick, H. (2020a). Le modèle de motivation-opportunité-capacité: Application à la mobilité étudiante régionale en Asie centrale [Applying the motivation-opportunity-ability model to regional student mobility in Central Asia]. Journal of International Mobility: Moving for Education, Training and Research, 7, 45-68.

Syed Zwick, H. (2020b). Narrative analysis of Syrians, South Sudanese and Libyans transiting in Egypt: A motivation-opportunity-ability approach. Journal of Ethnic and Migration Studies. https://doi.org/10.1080/1369183X.2020.1720630

Syed Zwick, H., \& Syed S. A. S. (2015). Student disinterest for mobility: Microeconomic determinants. Current Politics and Economics of Europe, 26(1), 93-108.

Triandis, H. C. (1977). Interpersonal behavior. Brooks/Cole.

UNESCO Institute for Stastistics. (2019). UNESCO Database on education. Retrieved Month 01, 2020, from http://data.uis.unesco.org/

Ullman, J. B. (2001). Structural equation modelling. In B. G. Tabachnick \& L. S. Fidell (Eds,), Using multivariate statistics (pp. 653-771). Allyn \& Bacon.

Urry, J. (2007). Mobilities. Polity.

Van der Velde, M., \& van Naerssen, T. (2015). The threshold approach revisited. In M. Van der Velde \& T. van Naerssen (Eds.), Mobility and migration choices: Thresholds to crossing borders (pp. 267-275). Ashgate.

Waters, J. (2008). Education, migration, and cultural capital in the Chinese diaspora: Transnational students between Hong Kong and Canada. Cambria Press.

HELENE SYED ZWICK, PhD, is executive director in the ESLSCA Research Center of Excellence (ERCE) at ESLSCA University Egypt. Her major research interests lie in the area of human mobility, return and reintegration, migrant decision-making. Email: helene.syed@eslsca.edu.eg 